\title{
Using research in the teaching of management
}

\author{
C. Orpen \\ Deakin University, Victoria, Australia
}

It is argued (i) that there is considerable scope for using research in teaching management, and (ii) that this does not require that the teacher be an active and expert researcher. A number of different ways of using research in teaching are discussed and suggestions provided for using them most effectively.

S. Afr. J. Bus. Mgmt. 1986, 17: $225-229$

In hierdie artikel word aangevoer dat: (i) daar heelwat ruimte is om navorsing binne bestuurstudies te gebruik, en (ii) dit nie vereis dat die dosent 'n aktiewe en deskundige navorser moet wees nie. 'n Aantal verskillende metodes in die gebruik van navorsing binne bestuurstudies word bespreek en voorstelle word gedoen om dit so effektief moontlik te doen.

S.Afr. Tydskr. Bodrytsl. 1986, 17: 225 - 229

\section{Orpen}

School of Management, Deakin University, Victoria, 3217, Australia
Whilst there is little data on the subject, few persons in universities can be unaware of the fact that there are significant differences in the attitudes of academics towards research, especially within schools of business (e.g. Gordon \& Howell, 1959). At the one extreme are academics who feel that research in management is very useful and is something in which all teachers should be actively engaged. At the other extreme are academics who believe that research should not take up too much of the time of a teacher of management, whose attention, they argue, should be devoted to teaching and consulting. They believe that both students and teachers benefit if research does not play a central role in the job of the teacher of management. Some who hold this view believe that scientific research in management is not possible, or at least does not lead to useful results (Orpen, 1986). However, the majority who believe that research should play only a minor role believe that this is because doing research stands in the way of being an excellent and committed teacher; that being involved in research is inconsistent with the main goal of ones job - that of training students to be better managers.

This is an attitude that encourages the view that research is something that can be separated from teaching, and that teachers of management not only need not do research, but that somehow doing research will make them poorer teachers. It is the aim of this paper to refute this notion. Contrary to the view just presented, it will be argued that (a) research is an integral part of teaching, and (b) there are a variety of ways in which teachers can use research - to improve their teaching - that do not require them to be active or experienced researchers themselves. As will be shown later, the belief that research and teaching can (and should) be separated is based on a narrow conception of research that restricts the view of the possibilities of using research in teaching. It is also supported by the outdated notion that unless one is personally involved in research, of the kind that leads to published papers, there is simply no way in which research can be employed to improve ones teaching. The present paper rejects these claims and presents ideas how research can be used to enliven and enrich the teaching process.

That the use of research in teaching is to be recommended rests on two main arguments. The first is that teaching and research are inextricably bound up with each other. For one thing, both are concerned with improving our understanding of what management and managing is about. They share the aim of helping us to grasp more fully than before what we need to know so that we can manage more effectively (cf. Dewey, 1963; Drucker, 1954). For another, both are also 
concerned with theory, merely looking at it from different perspectives, research in terms of developing and testing theory, teaching in terms of applying and further refining it (e.g. Kolb, 1984; Revans, 1974). The second argument supporting the use of research in teaching is that in a subject like management what is involved in doing research and in teaching effectively are very similar; i.e. the research process and the teaching process in management have many things in common. For instance, to really appreciate what they are taught about management, students need to be given practice in applying it to concrete situations, testing it against reality, and a chance to revise what they have learnt in the light of their experience. Without such opportunities and practice, the material that is taught is likely to be seen as irrelevant and incapable of being used effectively. Similarly, the most essential part of all research is the testing of hypotheses against reality in either experiments or surveys. The researcher in management applies something he or she has learnt to a concrete situation to see whether it is valid or not. If it is valid then the researcher, just like the student, moves on to something else; if it is not, he alters or modifies it in the light of the research findings (e.g. Argyris \& Shon, 1976; Revans, 1974).

According to Kolb, Rubin \& McIntyre (1984), the experience of learning about management typically involves a series of activities, characterized by:

(i) concrete experience;

(ii) observation and reflection;

(iii) formation of concepts and ideas; and

(iv) testing implications of ideas and concepts in new situations.

They argue that effective teachers recognize this and integrate their teaching into this natural type of experiential learning. These four steps are paralleled exactly by what is involved in doing research in management. The research process typically requires the researcher to:

(i) reflect and observe on his concrete experiences or reading;

(ii) develop hypotheses and theories;

(iii) devise research to test these theories and hypotheses; and

(iv) feed these results back into the research process. (Sashkin \& Morris, 1983).

Because teaching and research are so inextricably linked together and so alike in significant respects, clearly it is unwise to separate them from each other, to treat research as something that precedes teaching and is different from it, as is so often done (e.g. Beard, 1973; Powell, 1976). Accepting that research can, and should, be used to improve teaching, the next step is to indicate how this can be done.

\section{Incorporating research in teaching}

Probably the most obvious way of using research in teaching is to 'pass on' to students the outcomes of research conducted by oneself or others. Because there is a body of knowledge, mostly derived from the empirical research, about management, teachers have an obligation to inform students of it. They have a duty to tell students what researchers have found out about managing, and not to rely just on their own views and opinions, no matter how much these are based on their own varied experiences (Drucker, 1954; Bennett, 1984).

When teachers have carried out this research themselves, they should make a point of telling students about it, right down to personal details about how the research was conducted and whether it turned out as the researcher expected. Too often experienced researchers fail to provide students with personal accounts of their own research, confining themselves instead to a general and abstract account of what they found out. However, even when the teacher has not done any research him or herself, this should not be used as an excuse for failing to inject research into his or her teaching. As Sealack \& Williamson (1984) have pointed out, it is possible to attend courses in management that avoid any mention of any particular research study or empirical investigation. Besides failing in their duty and giving a false impression of their subject, teachers who follow this approach seldom excite their students or entice them to learn more about managing. For most students, giving them details about the research of others will make the subject more interesting and stimulating (Bennett, 1984). Provided the teacher provides students with sufficient detail about a few studies, they should also learn how researchers go about studying management and in a way that can induce them to learn more, perhaps even to do some research themselves (Orpen, 1986).

For this to occur, it is usually necessary for teachers to go beyond the confines of textbooks to the original articles in which the research is fully described. It is seldom that texts provide sufficient detail of particular research studies to have the desired impact on students. It is important that the teacher does not try to cover a lot of research superficially, emphasizing their varied results, but instead selects a few which are then treated in some depth.

\section{Using students as research subjects}

There has been a lot of criticism recently of orthodox or traditional approaches to teaching, in which the teacher's job is seen as transmitting knowledge, usually by means of lectures or seminars, to a number of students at the same time (e.g. Costin, 1982; Stones, 1976). Whilst this can be a very efficient method of teaching, research has shown that it is likely to be 'effective' only when (a) there is an accurate diagnosis of what the learner needs to know; (b) the teacher has the knowledge and ability to transfer knowledge effectively to students; and (c) there is no problem in the students' transferring this knowledge into effective practice later on (Wragg, 1974; McLeish, 1978). Unfortunately, these conditions are seldom obtained in management. For instance it is very difficult, if not impossible, to find out exactly what different students need to know to manage effectively (Leavitt, 1978). As we know, it is also the exception rather than the rule to find very skilful and motivated teachers of management who can fire the enthusiasm of their students (Mandt, 1982). Finally, there is a difference in management between knowing certain ideas or concepts and implementing them effectively. For one thing, there are no rules or formulae that can be used to ensure successful implementation (von der Embse, 1983). For another, to be effective managers, students need practice in diagnosing situations and applying what they have learnt and this is something that cannot be done just by attending lectures and seminars (Sealack \& Williamson, 1983).

To overcome these difficulties teachers of management are typically advised not to rely too much on lectures and seminars, but instead to employ things like cases, role-playing, projects and experiential exercises. I think research can play a vital role in helping these alternative approaches be more effective. There are at least three ways in which research can assist here, each using the fact that all students have had some experience of managing, even if only at the receiving end. In each case, students are required to do research on data they provide themselves, from their own experiences, instead of being told the results of research done elsewhere by another person. 
(i) Students can be divided into small groups whose members relate their own experiences of the same problem to each other. These experiences can be gathered from the groups and summarized, by the teacher, in the form of generalizations. These generalizations can be compared to the results of research findings to see whether they have been borne out or not. The aim is for students to try to establish the relationship between their generalizations and those uncovered by research.

(ii) In the opposite direction, the teacher can present the results of some research and get students to compare it with their own experiences. Small groups can be established in which students discuss whether their experiences in similar situations bear out the research findings. Representations from each group can be asked to 'explain' the group's 'findings' to the class. In following this procedure, the teacher must be careful to choose a piece of research that deals with problems that are familiar to most students (Bennett, 1984).

(iii) The members of the course, either as individuals or as members of small groups, can serve as subjects in 'research' conducted by the teacher as an integral part of the course. Because they seldom constitute anything like a 'representative' sample, teachers should be advised against using course members as subjects in research that requires tight experimental designs or controlled samples. However, when - as often happens in management we are merely concerned with judgements being made about something or people's reactions to particular approaches, ideas, or concepts to managing, then course members can (and should) provide useful information that helps the teacher. The process of providing the research data is an enjoyable one that should not only teach the student something about management but also show it to be a subject of immediate relevance to his or her own life (Sashkin \& Morris, 1983).

\section{Getting students to do research}

Another obvious, but effective, way of using research in teaching is to require students to undertake research as part of a course assignment, i.e. as something that counts towards their final mark on the course. There are a variety of activities students can do to fulfil such a requirement, none of which requires them to complete the kind of full-blown study found in the professional journals. Although their activities may not constitute experimental investigations and may not involve the large-scale testing of representative samples, students need to be explicitly reminded that they are still doing research; that they are conducting useful investigations which, in a humble way, are contributing to our store of knowledge of management. It is important that the teacher be mindful of the range of possibilities or options that are available, and not be constrained by what journal editors regard as 'scientific' or 'useful' research that can be published. Examples of the kinds of research activities that students can do fairly quickly and easily are:

(i) develop a short scale or questionnaire about work-related issues, distribute it to a small sample of employees, and produce a short report;

(ii) devise a set of questions and use them as the basis for interviews with local managers;

(iii) investigate what is happening in a few local firms with a view to developing conclusions about managerial effectiveness;

(iv) develop generalizations by observing members of the class performing specific learning exercises; and (v) write up their own experiences in doing learning exercises during class time.

All these activities produce 'data' that can be gathered from the students, analysed during class time, fed back to the class for further discussion, and perhaps accumulated over time. It is often feasible to get individuals to report their 'findings' to the rest of the class and require the class to make sense of those findings, as a specific exercise. In some cases, it is appropriate to compare the findings from the activity with research reported in the literature. The task given to the class can be to explain why (as often happens) their findings differ from those in the literature, and what this implies for management. Experience has shown that this method of involving students in research can generate a very high level of interest and motivation to learn about management (e.g., Bennett, 1984; Orpen, 1982).

\section{Using research instruments in the classroom}

Another way in which students can be involved in research, is by getting them to use instruments developed by researchers during actual class periods. A large amount of research in management involves the development of scales, questionnaires, check-lists and tests to measure attitudes, opinions, capacities and the like. Whereas some of these are too lengthy and cumbersome to be useful, there are some that can be completed and scored by students during part of a normal class period (cf., Pfeiffer \& Jones, 1983; Sashkin \& Morris, 1983). My experience is that these can be used to good effect in stimulating discussion and teaching students important lessons about research in management. No matter how the teacher decides to employ such instruments, it should be made clear to the students that in completing the instrument and analysing the results, they are, in effect, doing research with the added advantage of being able to take the perspective of the subject as well as the researcher.

The following is one way in which such instruments can be used to good effect, during a normal class period (say, one and a half hours): First, the teacher introduces the topic, and distributes the instrument to the class. Members of the class complete the instrument and score it themselves, according to instructions given out with the instrument. The students then return their 'scores' to the teacher who collates them in front of the class. Students are invited to compare their responses with the collated results and to think over the implications of the findings of the 'research' for management. Finally, after a period of stimulating discussion based firmly on the results of the research just conducted with the instrument, the teacher draws conclusions from the debate and relates them to the overall picture from research findings about management.

Instead of individuals feeding their 'scores' or 'responses' back to the teacher, they can discuss them in small groups of three or four, and write up group reports during class time. Provided the groups are told exactly what to do, this can be most effective. Experience has shown that students enjoy comparing their responses with those of others, especially when they exchange views and justify why they responded like they did. Students are usually more confident when talking to others in a small group situation, rather than speaking in front of the whole class. Using research instruments in these ways is consistent with my view that teachers in management need to 'stand aside' and let students learn from each other more than usually happens.

In order to employ instruments in either of these ways, the 
teacher need not be an expert or active researcher. All that is necessary is that he or she has access to the instruments and is willing to experiment with the class in these ways, using the students as researchers and subjects in improving their knowledge about management.

\section{Using personal case histories of students}

Whether they have worked as managers or not, all students of management have experiences of people managing things and others. They have all seen their parents planning and organizing things, they have all been involved at some time in running events like fetes and societies and outings, and they have all witnessed themselves or others do those things well or poorly. The effective teacher needs to get students to realize that there is a lot they can learn about management by reflecting carefully on such experiences of their own and by listening to what others have to say about them (Quaglino \& Testa, 1979).

It is clearly inappropriate to give students a completely free rein in reflecting on their experiences and listening to others. On the other hand, the teacher should not try to tell them what they are likely to find when they reflect on their own experiences and listen to those of others. In my view, what needs to be done is for the teacher to structure a learning situation, to design an exercise, within which students can reflect and listen to others. In such structures or designs, the teacher informs the students of the steps to follow and then 'stands aside' to let them get on with it. In practice, this typically requires the teacher to select a topic, give students a particular period in which to produce their own data, ask them to compare their data on a systematic basis, and then to try to make sense of their combined experiences. It is my view that students need to separate the activity of data generation from that of drawing conclusions about management from their data. To assist them in doing this, it is often helpful to get them to write down their experiences with no attempt at interpretation. And then, at a later point, ask them to indicate what these experiences mean or signify in general terms. It should be pointed out to the students that, in doing so, they are trying to develop generalizations about management in the same way as researchers about whom they read in their textbook. The only difference being that they rely on 'data' from their experiences, whereas the research relies upon data collected from an experiment or survey.

It has been my experience that for the personal history approach to work effectively, students need to be provided with help or assistance in the form of specific steps and things to take into account, provided that in doing so, the teacher does not affect the nature of the data the students produce or the kind of interpretation they place on it. The idea is merely to assist students to produce fuller and, richer case histories from which they can learn more than they would otherwise. What follows is a procedure that I have personally found most useful.

(i) A particular topic or problem is first selected for discussion.

(ii) Course members reflect back over recent events in their life that have a bearing on this topic or problem. They are required to be as concrete as possible and to actually write down the events and how they felt about what happened.

(iii) For each event the course members are asked to:

(a) identify what led up to the events described,

(b) specify the 'essence' of the event,

(c) describe its outcome, (d) indicate something about the principal characters, and

(e) reveal how they felt about the events and the actions taken by the principal characters.

(iv) The course members form small groups. In each group they share their events or cases with other members. Groups are told, quite specifically, that members be given turns in relating their cases to the others - who are required to listen without interrupting.

(v) Each group then selects one of the cases of their members which they feel most 'suitable' as a vehicle for discussion of the particular problem or topic.

(vi) All of these cases are distributed among the entire class. Working in their groups on these cases or personal histories, course members try to develop generalizations about management from them. Their task is to discern what these cases have to say about the topic or problem under discussion.

(viii) Finally, the teacher can lead a class discussion which centers around these cases and what they mean or imply for management. In such discussions, the teacher should give each group an opportunity, via a selected member, to tell the entire class what these personal histories have in common and what they signify or mean for the particular topic or problem. It is the task of the teacher, with the help of the class, to sum up the discussion and integrate the views expressed into the rest of the course.

There is obviously scope for varying these steps depending on circumstances. However, for our present purposes what is important is that students produce their own material and work on it, rather than on material supplied to them by others. Also that they are given a chance to try to make sense of data, instead of being supplied with the 'outcomes' arrived at by researchers and given to them by lecturers or by a textbook. The advantage of this approach is that students act as their own researchers on data that are important to them - because it is based on events they or their fellow students actually experienced.

To conclude, there are a variety of ways in which teachers can use research in teaching management without them necessarily being active or expert researchers themselves. It is up to the teacher to decide for him or herself which ones to employ in different circumstances. What the present article has attempted to show is that there are advantages in using research in teaching and that ways of doing so exist that are quite straightforward and easy to employ. In my view, the only $\sin$ is for teachers of management not to give them a try.

\section{References}

Argyris, C. \& Shon, D.A. 1976. Theory in practice: Increasing professional effectiveness. New York: Jossey-Bass.

Beard, R. 1973. Teaching and learning in higher education. London: Penguin.

Bennett, R. 1984. Management research. London: Heinemann.

Costin, F. 1982. Lecturing versus other methods of teaching. Br. J. Educ. Technol., vol. 13, 4-31.

Dewey, J. 1963. Education and experience. New York: Collier Macmillan.

Drucker, P. 1954. The practice of management. New York: McGraw-Hill.

Gordon, R.J. \& Howell, J.F. 1959. Higher education for business. New York: Columbia University Press.

Kolb, D. 1984. Experiential learning. Englewood-Cliffs, N.J.: Prentice-Hall.

Kolb, D., Rubin, I. \& McIntyre, J.M. 1984. Organizational Psychology: An experiential approach. Englewood-Cliffs, N.J.: Prentice-Hall. 
Leavitt, H.J. 1978. Management and management education in the West. London: London Business School.

Mandt, E.J. 1982. The failure of management education and what to do about it. Manage., vol. 26, 47-59.

McLeish, J. 1978. The lecture method. London: Cambridge University Press.

Orpen, C. 1982. Behaviour in work organizations: An intermediate text. Johannesburg: Jonathan Ball.

Orpen, C. 1986. Management education: Problems and prospects. Unpublished manuscript, School of Management, Deakin University, Victoria, Australia.

Pfeiffer, J.W. \& Jones, R.W. 1983. Handbook of structured experiences for human relations training. London: University Associates of Europe.

Powell, J.P. 1976. University teaching methods. In: Educational research in Britain. Butcher, H.J. \& Pont, H. (Eds.) London:
University of London Press, 116-130.

Quaglino, G.P. \& Testa, G. 1979. The use of personal case histories as a tool for management education. Manage. Educ. Dev., vol. 10, $112-123$.

Revans, R. 1974. Action learning. London: Macmillan.

Sashkin, M. \& Morris, W.C. 1983. Organizational behavior in action. New York: West Publishing.

Sealack, M.W. \& Williamson, H.F. 1984. The evolution of management education. Urbana, Ill.: University of Illinois Press.

Stones, E. 1976. Teaching teaching skills. Br. J. Educ. Technol., vol. 7, 60-77.

Von der Embse, T. 1983. Managerial ignorance or managerial savvy: Another view. Bus. Hor., 24-32.

Wragg, E.C. 1974. Teaching teaching. London: David and Charles. 